Ricardo Taufano, Irwansyah: Brand Personality Achmad Zaky Sebagai Chief Executive Officer Bukalapak Dalam Media Sosial Instagram

\title{
Brand Personality Achmad Zaky Sebagai Chief Executive Officer Bukalapak Dalam Media Sosial Instagram
}

\author{
Ricardo Taufano, Irwansyah \\ Program Pascasarjana Ilmu Komunikasi Universitas Indonesia, Jl. Salemba Raya No.4, RW.5, \\ Kenari, Kec. Senen, Kota Jakarta Pusat, Daerah Khusus Ibukota Jakarta 10430 \\ ricardo.taufano@gmail.com,dr.irwansyah.ma@gmail.com
}

Masuk tanggal : 02-02-2020, revisi tanggal : 11-05-2020, diterima untuk diterbitkan tanggal : 02-06-2020

\begin{abstract}
Social media has become an important medium for people in everyday communication activities. Social media use is not only limited for individuals, but also organization such as the government and corporation to convey and collect informations. One of the most popular social media is Instagram. As one of the most used social media, both individuals and firms use Instagram as a medium to build their image. As a founder and CEO of Bukalapak, Achmad Zaky uses Instagram to show the image he wants to build and perceived by the audience. This research attempt to see the identity built by Zaky through his Instagram account @ achmadzaky using the theory of brand personality. As a CEO, the image of Achmad Zaky could affect the image of the firm that he is in charge with. This assumption is supported by the phenomenon of the hashtag \#UninstallBukalapak in various social media platforms after Zaky threw a statement that many considered political in his social media account in February 14th 2019. Quantitative approached is used in this research with content analysis method. 58 Instagram post in @achmadzaky account are taken as sample during the period from December 7 th 2018 to May 5th 2019. To illustrate the comparation in the brand personality Zaky tried to convey, the author divide the data sample into two data set marked by the phenomenon of \#UninstallBukalapak. The purpose of this research is to find Achmad Zaky's brand personality through contents in his Instagram account before and after \#UninstallBukalapak. This research uses Aaker's brand personality dimension as the main analytical tool which consist of sincerity, excitement, competence, sophistication, and ruggedness dimensions. The result in two data sets shows that the most often appear dimensions are sincerity with 68,3\% and 76,5\%, excitement $75,6 \%$ and $52,9 \%$, and competence $82,9 \%$ and $76,5 \%$, while the number of contents after \#UninstallBukalapak phenomenon decreases significantly.
\end{abstract}

Keyword: brand identity, brand personality, content analysis, social media

\begin{abstract}
Abstrak
Media sosial merupakan media digital yang digunakan oleh banyak orang untuk melakukan komunikasi. Tidak hanya individu, namun organisasi seperti pemerintah dan perusahaan menggunakan media sosial untuk memberikan dan memperoleh informasi. Salah satu media sosial paling populer adalah Instagram. Sebagai salah satu media sosial yang paling banyak digunakan, banyak individu maupun perusahaan yang menggunakan Instagram sebagai medium untuk membangun citra. Sebagai seorang CEO dan pendiri perusahaan Bukalapak, Achmad Zaky menggunakan Instagram untuk menunjukkan citra yang ingin dibangun dan dilihat oleh khalayak. Penelitian ini berusaha melihat identitas yang ingin dibangun melalui akun instagram @achmadzaky dengan menggunakan teori brand personality. Sebagai CEO, citra Achmad Zaky mempunyai pengaruh terhadap citra
\end{abstract}


perusahaan yang dipimpin, yaitu Bukalapak. Asumsi ini diperkuat dengan adanya fenomena \#UninstallBukalapak di media sosial setelah Achmad Zaky melontarkan pernyataan yang dinilai politis oleh publik di akun Twitter miliknya pada 14 Februari 2019. Penelitian ini menggunakan pendekatan kuantitatif dengan metode analisis konten. Sampel yang digunakan adalah 58 post Instagram @achmadzaky pada periode 7 Desember 2018 hingga 5 Mei 2019. Untuk mendapatkan perbandingan brand personality yang ada dalam konten, peneliti membagi sampel data menjadi dua set data yang ditandai oleh fenomena \#UninstallBukalapak. Tujuan dari penelitian ini adalah untuk mengetahui brand personaliy Achmad Zaky melalui konten dari akun Instagramnya sebelum dan sesudah kemunculan \#UninstallBukalapak. Penelitian ini menggunakan teori brand personality dari Aaker sebagai alat analisis utama yang meliputi dimensi sincerity, excitement, competence, sophistication, dan ruggedness. Temuan dalam dua set data menunjukkan bahwa dimensi yang paling banyak muncul adalah sincerity sebesar $68,3 \%$ dan $76,5 \%$, excitement sebesar $75,6 \%$ dan $52,9 \%$, dan competence sebesar $82,9 \%$ dan $76,5 \%$, sedangkan jumlah konten setelah fenomena \#UninstallBukalapak berkurang secara signifikan.

Kata Kunci: analisis konten, brand personality, identitas merek, media sosial

\section{Pendahuluan}

Media sosial telah menjadi salah satu medium utama bagi manusia untuk mendapatkan dan menyampaikan informasi karena memiliki beragam fitur yang berbeda dan unik sehingga mampu menarik banyak pengguna (Sapoetri \& Pannindriya, 2019). Tidak hanya digunakan oleh individu, media sosial digunakan oleh organisasi untuk menyampaikan informasi (Rustono Faradi Marta, Fernando, \& Simanjuntak, 2019). Melalui media sosial, pengguna dapat memproduksi dan membagikan sebuah konten yang berisi informasi yang dapat dibagikan dengan pengguna lain. Dalam media sosial, terdapat keleluasaan pengguna dalam memproduksi konten sesuai dengan preferensi pengguna dan dapat disebarkan secara langsung melalui perangkat seperti telepon pintar dan komputer yang terhubung dengan internet.

Instagram menjadi salah satu media sosial paling populer yang digunakan oleh masyarakat. Dalam hasil survei WeAreSocial.net dan Hootsuite, Instagram menempati posisi ke tujuh di dunia berdasarkan jumlah pengguna. Instagram sebagai media sosial yang mengizinkan penggunanya berbagi foto dan video serta teks menjadikannya media sosial yang populer (Rustono Farady Marta, 2018).

Besarnya jumlah pengguna Instagram membuat orginisasi dan perusahaan berusaha untuk menemukan suatu cara untuk menciptakan nilai brand dan menarik minat pelanggan melalui konten media sosial agar lebih menonjol dari kompetitor (Teguh \& Ciawati, 2020). Hal ini dilakukan sebagai cara untuk mendapatkan perhatian konsumen. Untuk mencapai hal ini, bisnis perlu menemukan suatu cara untuk menciptakan nilai yang melebihi dimensi produk dan jasa yang ditawarkan. Salah satu cara yang dapat dilakukan oleh perusahaan dalam praktiknya adalah dengan menghubungkan brand dengan konsumen (Chang, 2014).

Brand personality merupakan salah satu aspek penting dalam membentuk identitas perusahaan. Hal ini diartikan sebagai elemen yang merefleksikan nilai perusahaan, kata dan tindakan dari pekerja dalam suatu perusahaan (Ritchey \& Keller, 2006 dalam Chang, 2014). Tidak hanya komunikasi secara langsung yang 
disampaikan oleh perusahaan yang dapat menciptakan nilai, namun juga individuindividu yang ada di dalamnya. Individu yang dapat mempengaruhi perusahaan meliputi pengguna sebuah brand, karyawan atau Chief Executive Officer (CEO) dari perusahan tersebut, atau pendukung brand (McCracken, 1989 dalam Maehle \& Supphellen, 2011).

Perilaku individu yang merepresentasikan sebuah perusahaan di media sosial dapat mempengaruhi citra perusahaan tersebut. Pada 14 Februari 2019, Achmad Zaky, pendiri dan CEO sebuah perusahaan berbasis digital yang bernama Bukalapak, membuat cuitan di akun Twitter @achmadzaky yang dinilai bermuatan politis. Hal ini memunculkan respon khalayak terkait pernyataan yang dilontarkan tersebut. Respon ini memuat komentar negatif melalui tagar \#UninstallBukalapak yang mendorong pengguna aplikasi Bukalapak untuk menghapus aplikasi tersebut. Tagar ini merupakan respon yang muncul dari khalayak di berbagai media sosial, termasuk Instagram.

Dalam akun Instagram @achmadzaky, terdapat lebih dari seratus ribu pengikut. Zaky membuat akun Instagram pada tahun 2014. Terhitung pada $14 \mathrm{Mei}$ 2019, akun @achmadzaky memiliki jumlah 952 konten yang diunggah dalam Instagram post. Akun ini memiliki tanda centang biru yang menandakan bahwa akun ini telah diverifikasi oleh Instagram sebagai tokoh publik. Ahmad Zaky juga mencantumkan informasi bahwa dirinya merupakan CEO dan pendiri dari Bukalapak di akun Instagram miliknya.

Dalam dimensi identitas brand, terdapat empat kategori yang meliputi: (1) brand sebagai produk; (2) brand sebagai organisasi; (3) brand sebagai orang; dan (4) brand sebagai simbol (Aaker, 2003 dalam Bendisch, Larsen, \& Trueman, 2013). CEO merupakan individu yang masuk dalam kategori brand sebagai orang, yang dianggap unik karena CEO merupakan individu yang tunduk pada kebutuhan beragam pemangku kepentingan, dan dipengaruhi oleh peran dan identitas sebagai manajer, serta pertimbangan mengenai hubungannya dengan brand perusahaan (Bendisch et al., 2013).

Respon pengguna media sosial terhadap Achmad Zaky dilayangkan kepada perusahaan yang dipimpinnya, yaitu Bukalapak melalui tagar \#UninstallBukalapak. Fenomena ini menunjukkan bahwa identitas individu yang memiliki asosiasi terhadap perusahaan memiliki hubungan dengan brand perusahaan. Dengan ketertarikan mengenai hubungan individu dan asosiasi terhadap sebuah brand, penelitian ini berusaha mengeksplorasi identitas brand yang ingin dibangun dalam elemen brand personality yang ditunjukkan oleh Achmad Zaky sebagai pendiri sekaligus CEO dari Bukalapak di akun Instagram @achmadzaky.

Unit analisis terdiri dari konten Instagram yang diunggah dalam akun @achmadzaky. Hal ini dilakukan mengingat bahwa Instagram merupakan media sosial berbasis pembagian foto dan video serta teks yang dapat menggambarkan konteks. Analisis terhadap konten di Instagram Achmad Zaky dilakukan dikarenakan akun ini memiliki jumlah pengikut yang lebih banyak dibandingkan akun Twitter miliknya, serta bentuk konten foto, video, dan teks yang terdapat dalam Instagram dapat menggambarkan brand personality yang ingin dibangun oleh Achmad Zaky. 


\section{Brand Identity}

Pada dasarnya, identitas brand muncul dari kegiatan-kegiatan yang dilakukan oleh perusahaan. Hal ini mengacu pada bagaimana sebuah perusahaan memberikan identitas terhadap dirinya sendiri (Nandan, 2007). Dalam identitas brand, terdapat sebuah set asosiasi brand yang unik, yang dikomunikasikan terhadap konsumen. Terdapat dua bentuk identitas brand, yaitu identitas inti dan identitas perpanjangan (Ghodeswar, 2008).

Identitas inti mengacu pada atribut fisik seperti profil pengguna, atribut produk, suasana toko, layanan, dan kinerja produk, sedangkan identitas perpanjangan merupakan elemen identitas yang diatur ke dalam kelompok kohesif dan bermakna yang menciptakan kesempurnaan dan tekstur brand tersebut (Ghodeswar, 2008). Identitas perpanjangan mengacu pada brand personality, hubungan, dan asosiasi simbol yang kuat. Sebuah perusahaan berusaha untuk memperlihatkan individualitas dan kekhasan kepada khalayak melalui identitas brand (Nandan, 2007).

Diperlukan sebuah penetapan yang jelas dan konsisten mengenai identitas brand yang dapat dilakukan dengan menghubungkan atribut brand dengan cara komunikasi yang dapat dipahami konsumen. Nilai emosional merupakan salah satu aspek penting dalam membangung identitas brand selain dengan penyampaian keuntungan-keuntungan fungsi (Ghodeswar, 2008). Perusahaan dapat menggunakan strategi branding untuk menyampaikan identitas dan nilai kepada konsumen dan pemangku kepentingan lainnya (Nandan, 2007).

Sebagai seorang pemimpin perusahaan, personal brand Achmad Zaky memiliki dampak terhadap perusahaan Bukalapak. Oleh karena itu, konten yang diunggah Achmad Zaky di media sosial dianggap sebagai upaya personal branding. Personal branding diartikan sebagai bagaimana seseorang membentuk kepribadian yang baik bagi mereka (Stevani \& Widayatmoko, 2017).

Penelitian ini berusaha untuk melihat identitas yang ingin dibangun oleh Achmad Zaky, secara khusus brand personality yang merupakan identitas perpanjangan dalam identitas brand. Hal ini dilakukan mengingat bahwa sebagai pendiri dan CEO, Achmad Zaky memiliki asosiasi terhadap perusahaan yang dipimpin, yaitu Bukalapak. Sebagai CEO, tindakan yang dilakukan dapat mempengaruhi brand perusahaan (Bendisch et al., 2013). Melalui brand personality, peneliti berusaha melihat identitas yang ingin dibangun oleh Achmad Zaky melalui akun Instagram @achmadzaky.

\section{Brand Personality}

Secara historis, manusia mengasosiasikan ciri-ciri kepribadian terhadap objek dan memberikan karakteristik seperti manusia. Hal ini dilakukan untuk dapat memahami suatu fenomena dengan lebih baik (Lieven, 2018). Dapat diartikan bahwa seseorang menilai benda mati dengan cara yang sama saat mereka menilai orang lain (Govers and Schoormans, 2005 dalam Lieven, 2018).

Dari cara manusia mengasosiasikan kepribadian terhadap benda mati, muncul konsep yang disebut sebagai brand personality. Jennifer L. Aaker (1997) mendefinisikan brand personality sebagai karakterisitik manusia yang diasosiasikan dengan sebuah brand. Kepribadian merupakan salah satu elemen dari 
identitas brand yang ingin dicapai yang dapat merefleksikan citra diri yang sesungguhnya maupun aspirasional dari pemangku kepentingan (Chematony, 1999).

Ciri-ciri dari brand personality yang diasosiakan terhadap sebuah brand dipengaruhi oleh orang-orang yang merepresentasikannya. Orang-orang ini meliputi pengguna sebuah brand, karyawan atau CEO dari perusahaan tersebut, atau pendukung brand tersebut (McCracken, 1989 dalam Maehle \& Supphellen, 2011). Melalui pandangan ini, brand personality tidak hanya dapat digunakan untuk melihat persepsi khalayak terhadap suatu brand, namun juga dapat digunakan untuk melihat kepribadian yang ingin dibangun oleh suatu brand melalui individu yang ada di dalamnya.

Dalam taksonomi brand personality, terdapa lima dimensi utama yang meliputi sincerity, excitement, competence, sophistication, dan ruggedness (Aaker, 1997). Terdapat lima belas aspek yang tersebar dalam dimensi utama brand personality dengan empat puluh dua ciri kepribadian yang tersebar dalam aspekaspek tersebut. Dimensi sincerity memiliki ciri-ciri seperti sederhana, berorientasi keluarga, dan ramah. Dimensi excitement memiliki ciri-ciri seperti imajinatif, unik, dan terkini. Dimensi competence memiliki ciri-ciri seperti bekerja keras, pintar, dan percaya diri. Dimensi sophistication memiliki ciri-ciri seperti glamor, rupawan, dan menawan. Dimensi ruggedness meliputi ciri seperti kegiatan di luar ruangan, maskulin, dan kuat.

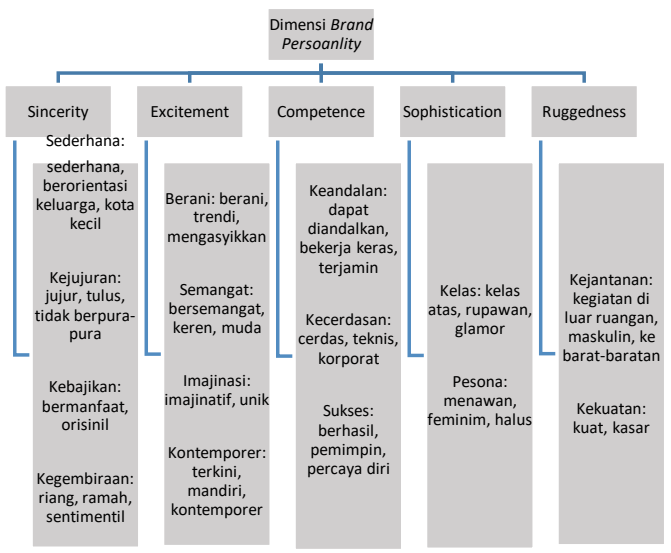

Gambar 1: Dimensi Brand Personality (Sumber: Aaker, 1997)

Konten berupa foto dan video yang terdapat dalam Instagram dimanfaatkan oleh individu maupun perusahaan untuk membangun brand personality. Khalayak dapat mengidentifikasi brand personality yang berusaha disampaikan oleh perusahaan. Selain itu, khalayak juga dapat memaknai dan memberikan makna terhadap brand, sehingga perusahaan perlu mengetahui bagaimana khalayak melihat dan memahami kepribadian yang ingin ditunjukkan oleh perusahaan. melalui pandangan ini, peneliti berusaha memahami bagaimana Achmad Zaky sebagai pendiri dan CEO Bukalapak menunjukkan brand personality di Instagram.

Berdasarkan pemaparan di atas, pertanyaan penelitian yang ingin dijawab adalah, apa brand personality yang ditunjukkan oleh Achmad Zaky di akun Instagram @achmadzaky sebelum dan sesudah kemunculan tagar 
\#UninstallBukalapak. Hipotesis dalam penelitian ini adalah Ho: terdapat perbedaan dalam brand personality yang ditunjukkan Achmad Zaky di akun Instagram @achmadzaky sebelum dan sesudah kemunculan tagar \#UninstallBukalapak. Ha: tidak terdapat perbeedan dalam brand personality yang ditunjukkan Achmad Zaky di akun Instagram @achmadzaky sebelum dan sesudah kemunculan tagar \#UninstallBukalapak.

\section{Metode Penelitian}

Dalam penelitian ini, peneliti berusaha menganalisis secara komprehensif konten foto, video, dan teks Achmad Zaky dalam akun Instagram @achmadzaky melalui konsep brand personality menggunakan teknik metode analisis konten dengan pendekatan kuantitatif.

Metode analisis konten dapat didefinisikan sebagai teknik penelitian untuk menghasilkan kesimpulan yang valid dan dapat direplikasi dalam teks (atau bentuk lain yang memiliki makna) ke dalam konteks penggunaannya (Krippendorff, 2004 dalam White \& Marsh, 2006). Metode ini menggunakan teknik yang menghasilkan matriks data yang cocok dengan analisis statistik melalui pemetaan data simbolik (Roberts, 2015).

Teks tidak hanya terdiri dari tulisan, namun juga dapat berupa gambar. Metode ini dapat digunakan untuk menganalisis artefak budaya seperti buku, lukisan, hingga inovasi teknologi (Roberts, 2015). Pada dasarnya, metode ini berusaha memetakan atribusi yang terdapat dalam teks ke dalam sebuah matriks yang dapat dikuantifikasi (Rustono Farady Marta, Fernando, \& Kurniawati, 2020). Penelitian ini berusaha memetakan atribusi yang terdapat dalam foto, video, dan teks yang diunggah oleh akun @achmadzaky di Instagram dan berusaha memetakan ke dalam sebuah matriks data yang dikuantifikasi berdasarkan konsep brand personality.

Penelitian ini adalah jenis penelitian deskriptif. Penelitian kuantitatif deskriptif diartikan sebagai upaya untuk mendeskripsikan situasi khusus, aturan sosial, atau hubungan secara spesifik (Neuman, 2014). Oleh karena itu, penelitian ini berupaya untuk menggambarkan variabel-variabel yang muncul dalam teks. Penggambaran dalam penelitian ini berusaha medeskripsikan situasi khusus terkait brand personality yang ditunjukkan oleh Achmad Zaky melalui akun Instagram @achmadzaky.

Terhitung hingga 14 Mei 2019, akun Instagram @achmadzaky memiliki populasi data berupa konten foto dan video yang berjumlah 952. Untuk menentukan sampel, peneliti menggunakan teknik purposive sampling. Teknik ini digunakan untuk mengidentifikasi jawaban dari pertanyaan penelitian secara akurat dan menyeluruh (White \& Marsh, 2006).

Dalam penelitian ini, peneliti menentukan dua bentuk set data untuk menjawab pertanyaan penelitian. Sampel diambil berdasarkan konten yang diunggah pada periode 5 Desember 2018 hingga 5 Mei 2019, yaitu sebelum kemunculan tagar \#UninstallBukalapak, sehingga didapat total sampel dengan jumlah 58 foto dan video. Untuk menjawab dua pertanyaan dalam penelitian ini, peneliti membagi sampel menjadi dua set data dengan rentang waktu yang sama, 
Ricardo Taufano, Irwansyah: Brand Personality Achmad Zaky Sebagai Chief Executive Officer Bukalapak Dalam Media Sosial Instagram

yaitu konten yang diunggah pada periode 5 Desember 2018 hingga 13 Februari 2019, yaitu setelah kemunculan tagar \#UninstallBukalapak sebagai set data pertama yang berjumlah 41 foto dan video. Konten yang diunggah pada periode 14 Februari 2019 hingga 5 Mei 2019 merupakan set data kedua yang berjumlah 17 foto dan video.

Pembagian set data dari jumlah keseluruhan sampel dilakukan dikarenakan penelitian ini berusaha melihat perbedaan brand personality yang terdapat dalam akun Instagram @achmadzaky sebelum dan setelah fenomena \#UninstallBukalapak yang merupakan respon terhadap Achmad Zaky terkait pernyataannya di media sosial.

Dalam penelitian ini, terdapat dua teknik pengumpulan data, yaitu pengolahan dokumen dan observasi. Pengolahan dokumen dilakukan terhadap foto dan video yang diunggah oleh akun Instagram @achmadzaky. Teknik pengumpulan data melalui observasi dilakukan dengan melakukan identifikasi terhadap indikator brand personality yang terdapat dalam foto dan video di akun Instagram milik Achmad Zaky.

Dalam melakukan observasi, penelitian ini menggunakan dimensi brand personality yang dikembangkan oleh Aaker (1997). Terdapat lima variabel yang terdiri dari sincerity, excitement, competence, sophistication, dan ruggedness. Dari lima variabel, terdapat ciri-ciri yang terdapat dalam masing-masing variable yang dikembangkan menjadi 42 indikator yang dapat diamati. Menurut Aaker (1997), brand personality memiliki ciri-ciri yang dapat diamati berdasarkan sifat-sifat manusia. Terdapat lima dimensi dari brand personality yaitu, sincerity, excitement, competence, sophistication, dan ruggedness.

Sincerity diartikan sebagai individu atau perusahaan yang memiliki kepribadian yang tulus dengan ciri-ciri seperti kesederhanaan, berorientasi pada keluarga, tulus, nyata, bermanfaat, ceria, ramah, dan sentimentil. Dimensi Excitement merupakan kepribadian yang gembira dengan ciri-ciri seperti berani, trendi, asyik, bersemangat, keren, muda, imajinatif, unik, mengikuti isu dan tren terkini, mandiri, dan modern.

Dalam spektrum kepribadian, dimensi competence digambarkan sebagai individu atau perusahaan yang berusaha memperlihatkan kompetensinya. Ciri-ciri yang dapat diamati dalam dimensi ini adalah dapat diandalkan, bekerja keras, mapan, cerdas, menunjukkan kapasitas teknis, peran dalam perusahaan, sukses, pemimpin, dan percaya diri. Dimensi lain yang ada dalam brand personality adalah sophistication, yang diartikan sebagai pribadi yang menggambarkan keindahan dengan ciri-ciri seperti gaya hidup kelas atas, individu yang rupawan, menarik, menawan dan feminim, serta memiliki tutur kata yang halus.

Dimensi terakhir dari brand personality adalah ruggedness, yang diartikan sebagai pribadi yang kasar. Individu yang memiliki kepribadian ini berusaha menunjukkan dirinya yang maskulin, menampilkan kekuatan, melakukan aktivitas menantang di luar ruangan, terpengaruh Barat, dan individu yang kasar.

Untuk menjamin pengukuran yang tepat dalam sebuah penelitian sehingga didapatkan data yang valid, diperlukan pengujian validitas yang mengacu pada tingkat representasi yang dihasilkan melalui proses pengukuran terkait konsep yang digunakan (Neuendorf, 2002 dalam White \& Marsh, 2006). Penelitian ini 
menggunakan validitas muka yang merupakan salah satu cara untuk menilai validitas dalam sebuah penelitian analisis konten. Tipe validitas ini merupakan penilaian dari komunitas ilmiah mengenai indikator yang digunakan sebagai alat ukur (Neuman, 2014). Pada dasarnya, validitas muka bersifat subjektif sehingga peneliti diharapkan dapat menilai seobjektif mungkin dalam pengukurannya (White \& Marsh, 2006).

Pada aspek reliabilitas, penelitian ini menguji penilaian yang dilakukan oleh dua penilai dalam menggunakan alat ukur. Teknik untuk mengukur tingkat reliabilitas yang digunakan dalam penelitian ini adalah reliabilitas antar penilai (intercoder realibility). Pengujian dilakukan melalui analisis yang dilakukan oleh dua penilai terhadap sampel yang sama (Potter \& Levine-Donnerstein, 1999). Untuk pengujian reliabilitas antar penilai, diambil 10 sampel foto dan video dalam Instagram@achmadzaky dan dilakukan analisis dengan menggunakan indikator dari brand personality yang ditentukan sebelumnya. Pengujian dilakukan dengan menggunakan formula Scott's Pi dan Cohen's Kappa. Hal ini ditujukan untuk melihat tingkat persetujuan kedua penilai terhadap alat ukur yang digunakan.

Untuk melihat reliabilitas antar penilai, dilakukan pengujian dengan menggunakan formula Scott's Pi dan Cohen's Kappa yang ditujukan untuk melihat tingkat persetujuan kedua penilai terhadap alat ukur yang digunakan. Melalui pengujian dengan kedua rumus tersebut, didapatkan hasil sebagai berikut:

Tabel 1. Hasil Uji Realibilitas Antar Penilai Dengan 10 Sampel Data

\begin{tabular}{l|lll}
\hline & $\begin{array}{l}\text { Percent } \\
\text { Agreement }\end{array}$ & Scott's Pi & Cohen's Kappa \\
\hline $\begin{array}{l}\text { Variable 1 } \\
\text { (cols 1 \& 2) }\end{array}$ & $100 \%$ & 1 & 1 \\
$\begin{array}{l}\text { Variable 2 } \\
\text { cols 3 \& 4) }\end{array}$ & $80 \%$ & 0.375 & 0.375 \\
$\begin{array}{l}\text { Variable 3 } \\
\text { cols 5 \& 6) }\end{array}$ & $80 \%$ & 0.583 & 0.6 \\
$\begin{array}{l}\text { Variable 4 } \\
\text { cols 7 \& 8) }\end{array}$ & $100 \%$ & 1 & 1 \\
$\begin{array}{l}\text { Variable 5 } \\
\text { cols 9 \& 10) }\end{array}$ & $100 \%$ & 1 & 1 \\
\hline
\end{tabular}

Berdasarkan hasil di atas, terdapat tiga variabel yang memiliki kesepakatan sempura, satu variabel dengan nilai 0.375 , dan satu variabel dengan nilai 0.6. Menurut Cohen, hasil dari penghitungan realibilitas dengan menggunakan rumus Kappa dapat diinterpretasikan sebagai berikut: $\leq$ sebagai indikasi tidak ada persetujuan, $0.01-0.20$ sebagai tidak ada atau sangat sedikit persetujuan, $0.21-$ 0.40 sebagai tingkat persetujuan yang cukup, $0.41-0.60$ sebagai tingkat persetujuan yang moderat, 0.61-0.80 sebagai tingkat persetujuan yang substansial, dan 0.81 -1.00 sebagai persetujuan hampir sempurna. Secara garis besar, penilaian yang dilakukan oleh dua penilai memiliki tingkat reliabilitas yang baik, dengan nilai minimum pada variabel 2 dengan tingkat persetujuan yang cukup. 
Ricardo Taufano, Irwansyah: Brand Personality Achmad Zaky Sebagai Chief Executive Officer Bukalapak Dalam Media Sosial Instagram

\section{Hasil Penemuan dan Diskusi}

Penelitian ini berusaha melihat brand personality yang ditunjukkan melalui konten berupa foto dan video di Instagram @achmadzaky. Secara keseluruhan, penelitian ini memiliki sampel 58 foto dan video yang diunggah dari 5 Desember 2018 hingga 5 Mei 2019. Identifikasi dilakukan berdasarkan indikator-indikator yang terdapat dalam dimensi brand peronality, yaitu sincerity, excitement, competence, sophistication, dan ruggedness.

Untuk menjawab pertanyaan dalam penelitian ini, peneliti membagi hasil temuan berdasarkan dua periode, yaitu 5 Desember 2018 hingga 13 Februari 2019 yaitu sebelum tagar \#UninstallBukalapak sebagai set data satu untuk menjawab pertanyaan penelitian pertama, dan periode 14 Februari 2019 hingga 5 Mei 2019 yaitu setelah kemunculan tagar \#UninstallBukalapak sebagai data set dua untuk menjawab pertanyaan penelitian kedua. Hal ini dilakukan untuk melihat adanya perbedaan dari hasil analisis yang dilakukan terhadap dua set data, mengingat adanya respon terhadap pernyataan Achmad Zaky yang dinilai politis di media sosial pada 14 Februari 2019 sehingga menimbulkan respon dari khalayak melalui tagar \#UninstallBukalapak di berbagai media sosial, termasuk Instagram.

\section{Brand Personality Achmad Zaky Sebelum Kemunculan Tagar \#UninstallBukalapak}

Dalam set data pertama, terdapat 41 konten berupa foto dan video yang dijadikan unit analisis. Tabel berikut menggambarkan frekuensi dimensi dari brand personality yang muncul dalam set data pertama.

\begin{tabular}{rllll}
\multicolumn{2}{c}{} & \multicolumn{2}{c}{ Tabel 2. Brand Personality } \\
No & Dimensi & Total & Presentase \\
\hline 1 & Sincerity & 28 & $68.3 \%$ \\
2 & Excitement & 31 & $75.6 \%$ \\
3 & Competence & 34 & $82.9 \%$ \\
4 & Sophistication & 6 & $14.6 \%$ \\
5 & Ruggedness & 12 & $29.3 \%$
\end{tabular}

Berdasarkan tabel di atas, dapat dilihat bahwa dimensi competence merupakan dimensi dengan persentase terbesar. Excitement merupakan dimensi kedua dengan persentase terbanyak setelah competence, disusul dengan dimensi sincerity. Dimensi dengan frekuensi terendah adalah sophistication dan dimensi ruggedness. 
Tabel 3. Sincerity

\begin{tabular}{rlll}
\hline No & Indikator & Jlh & Persentase \\
\hline 1 & Menunjukkan pribadi yang bersahaja & 2 & $4.9 \%$ \\
\hline 2 & Menunjukkan pribadi yang sayang keluarga & 4 & $9.8 \%$ \\
\hline 3 & $\begin{array}{l}\text { menunjukkan pribadi yang datang dan berorientasi } \\
\text { pada kota kecil }\end{array}$ & 2 & $4.9 \%$ \\
\hline 4 & Menunjukkan pribadi yang jujur & 5 & $12.2 \%$ \\
\hline 5 & Menunjukkan pribadi yang tulus & 13 & $31.7 \%$ \\
\hline 6 & Menunjukkan tindakan nyata & 12 & $29.3 \%$ \\
\hline 7 & Menunjukkan dirinya sebagai pribadi yang bermanfaat & 14 & $34.1 \%$ \\
\hline 8 & $\begin{array}{l}\text { Menunjukkan dirinya sebagai pribadi yang orisinil } \\
\text { (bukan imitasi) }\end{array}$ & 5 & $12.2 \%$ \\
\hline 9 & Menunjukkan pribadi yang ceria & 12 & $29.3 \%$ \\
\hline 10 & Menunjukkan dirinya sebagai pribadi yang ramah & 14 & $34.1 \%$ \\
\hline 11 & Menunjukkan konten sentimentil & 13 & $31.7 \%$ \\
\hline
\end{tabular}

Untuk menggambarkan hasil yang lebih komprehensif, peneliti berusaha memaparkan frekuensi dari indikator yang muncul dalam tiap dimensi dari brand personality. Tabel berikut menggambarkan frekuensi dari indikator yang terdapat dalam dimensi sincerity.

Berdasarkan hasil temuan, indikator yang paling sering muncul adalah konten yang menunjukkan keramahan dan pribadi yang bermanfaat dengan persentase yang sama, yaitu $34.1 \%$ dengan jumlah konten sebanyak 14. Indikator yang paling sering muncul setelah keramahan dan pribadi yang bermanfaat adalah ketulusan dan konten yang sentimentil dengan persentase yang sama. Sementara indikator yang memiliki persentase paling sedikit adalah pribadi bersahaja dan orientasi terhadap kota kecil, keduanya memiliki persentase sebesar $4.9 \%$ dengan jumlah sebanyak 2 konten. 
Ricardo Taufano, Irwansyah: Brand Personality Achmad Zaky Sebagai Chief Executive Officer Bukalapak Dalam Media Sosial Instagram

Tabel 4. Excitement

\begin{tabular}{rlll}
\hline No & Indikator & Jumlah & Persentase \\
\hline 1 & Menunjukkan dirinya sebagai pribadi yang berani & 2 & $4.9 \%$ \\
\hline 2 & Menunjukkan dirinya sebagai pribadi yang trendi & 3 & $7.3 \%$ \\
\hline 3 & $\begin{array}{l}\text { Menunjukkan dirinya sebagai pribadi yang } \\
\text { mengasyikkan }\end{array}$ & 11 & $26.8 \%$ \\
\hline 4 & $\begin{array}{l}\text { Menunjukkan dirinya sebagai pribadi yang } \\
\text { bersemangat }\end{array}$ & 17 & $41.5 \%$ \\
\hline 5 & Menunjukkan dirinya sebagai pribadi yang keren & 9 & $21.9 \%$ \\
\hline 6 & Menunjukkan dirinya sebagai pribadi yang muda & 4 & $9.8 \%$ \\
\hline 7 & $\begin{array}{l}\text { Menunjukkan dirinya sebagai pribadi yang imaginatif } \\
8\end{array}$ & 12 & $29.3 \%$ \\
\hline 9 & $\begin{array}{l}\text { Menunjukkan dirinya sebagai pribadi yang unik } \\
\text { isu dan tren terkini }\end{array}$ & 4 & $9.8 \%$ \\
\hline 10 & $\begin{array}{l}\text { Menunjukkan dirinya sebagai pribadi yang mandiri } \\
11\end{array}$ & $\begin{array}{l}\text { Menunjukkan dirinya sebagai pribadi yang } \\
\text { kontemporer/modern }\end{array}$ & 0 \\
\hline
\end{tabular}

Dalam dimensi excitement, indikator yang paling banyak ditemukan adalah indikator yang menunjukkan pribadi yang bersemangat sedangkan indikator terbanyak kedua adalah indikator imajinatif. Empat indikator yang mendominasi dalam dimensi ini terdiri dari semangat, imajinatif, keren, dan mengasyikkan. Tidak ditemukan adanya konten yang menunjukkan indikator mandiri.

Tabel 5. Competence

\begin{tabular}{|c|c|c|c|}
\hline No & Indikator & Jumlah & Persentase \\
\hline 1 & $\begin{array}{l}\text { Menunjukkan dirinya sebagai pribadi yang bisa } \\
\text { diandalkan }\end{array}$ & 8 & $19.5 \%$ \\
\hline 2 & $\begin{array}{l}\text { Menunjukkan dirinya sebagai pribadi yang bekerja } \\
\text { keras }\end{array}$ & 12 & $29.3 \%$ \\
\hline 3 & Menunjukkan dirinya sebagai pribadi yang mapan & 3 & $7.3 \%$ \\
\hline 4 & $\begin{array}{l}\text { Menunjukkan dirinya sebagai pribadi yang } \\
\text { cerdas }\end{array}$ & 12 & $29.3 \%$ \\
\hline 5 & Menunjukkan kapasitas dalam hal teknis & 3 & $7.3 \%$ \\
\hline 6 & Menunjukkan peran di perusahaan & 28 & $68.3 \%$ \\
\hline 7 & Menunjukkan dirinya sebagai orang yang sukses & 15 & $36.6 \%$ \\
\hline 8 & Menunjukkan dirinya sebagai pemimpin & 19 & $46.3 \%$ \\
\hline 9 & $\begin{array}{l}\text { Menunjukkan dirinya sebagai pribadi yang memiliki } \\
\text { kepercayaan diri }\end{array}$ & 13 & $31.7 \%$ \\
\hline
\end{tabular}


Competence merupakan dimensi brand personality yang paling sering muncul dalam sampel yang dianalisis. Indikator yang mendominasi dalam dimensi ini adalah peran di perusahaan, disusul dengan indikator yang menunjukkan dirinya sebagai pemimpin. Indikator terbanyak ketiga adalah konten yang menunjukkan kesuksesan, disusul dengan indikator percaya diri dengan persentase. Indikator yang paling jarang muncul adalah indikator yang menunjukkan kemapanan dan hal teknis dengan persentase yang sama.

Tabel 6. Sophistication

\begin{tabular}{r|lll}
\hline No & Indikator & Jumlah & Persentase \\
\hline 1 & Menunjukkan gaya hidup kelas atas & 0 & $0.0 \%$ \\
2 & Menunjukkan dirinya sebagai individu yang rupawan & 3 & $7.3 \%$ \\
3 & Menunjukkan dirinya sebagai individu yang menarik & 0 & $0.0 \%$ \\
4 & Menunjukkan dirinya sebagai individu yang menawan & 6 & $14.6 \%$ \\
5 & Menunjukkan dirinya sebagai individu yang feminim & 0 & $0.0 \%$ \\
6 & Menunjukkan dirinya bertutur kata halus & 6 & $14.6 \%$ \\
\hline
\end{tabular}

Dimensi sophistication merupakan dimensi dengan frekuensi kemunculan paling rendah. Indikator dengan frekuensi kemunculan terbanyak adalah menunjukkan dirinya sebagai individu rupawan dan tutur kata halus. Terdapat tiga indikator yang tidak ditemukan yaitu gaya hidup kelas atas, pribadi yang menarik, dan feminim.

Tabel 7. Ruggedness

\begin{tabular}{|c|c|c|c|}
\hline No & Indikator & Jumlah & Persentase \\
\hline 1 & $\begin{array}{l}\text { Menunjukkan dirinya sebagai individu yang menyukai } \\
\text { kegiatan di luar ruangan }\end{array}$ & 2 & $4.9 \%$ \\
\hline 2 & Menunjukkan dirinya sebagai individu yang maskulin & 0 & $0.0 \%$ \\
\hline 3 & $\begin{array}{l}\text { Menunjukkan dirinya sebagai individu yang } \\
\text { mengadopsi pengaruh Barat }\end{array}$ & 12 & $29.3 \%$ \\
\hline 4 & Menunjukkan dirinya sebagai individu yang kuat & 0 & $0.0 \%$ \\
\hline 5 & Menunjukkan dirinya sebagai individu yang kasar & 0 & $0.0 \%$ \\
\hline
\end{tabular}

Ruggedness merupakan dimensi dengan frekuensi terendah kedua setelah dimensi sophistication dengan persentase sebesar 29.3\%. Dimensi ini didominasi oleh indikator adopsi pengaruh Barat, disusul dengan indikator yang menunjukkan dirinya sebagai pribadi yang menyukai kegiatan di luar ruangan.

Pemaparan temuan di atas merupakan hasil analisis terhadap set data pertama yang terdiri dari 41 sampel selama periode 5 Desember 2018 hingga 2019. Pada set data kedua, periode pengambilan sampel dilakukan dengan durasi waktu yang sama dengan set data pertama. Dalam set data kedua, sampel yang terdapat dalam kurun waktu 14 Februari hingga 5 Mei 2019 terdiri dari 17 unggahan berupa foto dan video di Instagram. 


\section{Brand Personality Achmad Zaky Setelah Kemunculan Tagar \#UninstallBukalapak}

Dalam set data kedua, terdapat dua dimensi yang paling sering muncul dengan frekuensi yang sama, yaitu sincerity dan competence, dengan persentase sebesar $76.5 \%$ dengan konten sebanyak 13. Dimensi terbanyak ketiga adalah dimensi excitement dengan persentase sebesar 52.9\% dengan konten sebanyak 9, disusul dengan dimensi sophistication dengan presentase sebesar $35.3 \%$ dengan jumlah konten sebanyak 6. Dimensi dengan frekuensi terendah merupakan dimensi ruggedness dengan persentase sebesar $23.5 \%$ dengan total sebanyak 4 konten.

Penggambaran hasil yang lebih komprehensif pada data set kedua juga dilakukan dengan memaparkan frekuensi dari indikator yang muncul dalam setiap dimensi dari brand personality. Frekuensi indikator yang akan dibahas dimulai dari dimensi sincerity hingga dimensi ruggedness.

Tabel 8. Sincerity

\begin{tabular}{|c|c|c|c|}
\hline No & Indikator & Jumlah & Persentase \\
\hline 1 & Menunjukkan pribadi yang bersahaja & 4 & $23.5 \%$ \\
\hline 2 & Menunjukkan pribadi yang sayang keluarga & 6 & $35.3 \%$ \\
\hline 3 & $\begin{array}{l}\text { menunjukkan pribadi yang datang dan berorientasi } \\
\text { pada kota kecil }\end{array}$ & 2 & $11.8 \%$ \\
\hline 4 & Menunjukkan pribadi yang jujur & 0 & $0.0 \%$ \\
\hline 5 & Menunjukkan pribadi yang tulus & 3 & $17.6 \%$ \\
\hline 6 & Menunjukkan tindakan nyata & 2 & $11.8 \%$ \\
\hline 7 & Menunjukkan dirinya sebagai pribadi yang bermanfaat & 4 & $23.5 \%$ \\
\hline 8 & $\begin{array}{l}\text { Menunjukkan dirinya sebagai pribadi yang orisinil } \\
\text { (bukan imitasi) }\end{array}$ & 1 & $5.9 \%$ \\
\hline 9 & Menunjukkan pribadi yang ceria & 4 & $23.5 \%$ \\
\hline 10 & Menunjukkan dirinya sebagai pribadi yang ramah & 6 & $35.3 \%$ \\
\hline 11 & Menunjukkan konten sentimentil & 6 & $35.3 \%$ \\
\hline
\end{tabular}

Hasil temuan dalam dimensi ini menunjukkan bahwa terdapat tiga indikator yang memiliki frekuensi terbanyak, yaitu indikator orientasi kepada keluarga, keramahan, dan sentimentil. Ketiga indikator ini memiliki persentase yang sama. Selain ketiga indikator tersebut, terdapat tiga indikator lain yang memiliki jumlah persentase terbanyak kedua, yaitu konten yang menunjukkan pribadi yang bersahaja, bermanfaat, dan ceria. Tidak ditemukan adanya konten yang menunjukkan indikator kejujuran. Selain indikator ini, frekuensi kemunculan terendah terdapat pada indikator orisinalitas.

Selain itu, terdapat indikator orientasi pada kota kecil dan tindakan nyata dengan persentase yang sama. Indikator yang menunjukkan pribadi yang tulus memiliki frekuensi kemunculan dengan persentase sebesar $17.6 \%$ yang terdapat dalam 3 konten Instagram. 
Tabel 9. Excitement

\begin{tabular}{|c|c|c|c|}
\hline No & Indikator & Jumlah & Persentase \\
\hline 1 & Menunjukkan dirinya sebagai pribadi yang berani & 0 & $0.0 \%$ \\
\hline 2 & Menunjukkan dirinya sebagai pribadi yang trendi & 1 & $5.9 \%$ \\
\hline 3 & $\begin{array}{l}\text { Menunjukkan dirinya sebagai pribadi yang } \\
\text { mengasyikkan }\end{array}$ & 4 & $23.5 \%$ \\
\hline 4 & Menunjukkan dirinya sebagai pribadi yang bersemangat & 10 & $58.8 \%$ \\
\hline 5 & Menunjukkan dirinya sebagai pribadi yang keren & 1 & $5.9 \%$ \\
\hline 6 & Menunjukkan dirinya sebagai pribadi yang muda & 1 & $5.9 \%$ \\
\hline 7 & Menunjukkan dirinya sebagai pribadi yang imaginatif & 4 & $23.5 \%$ \\
\hline 8 & Menunjukkan dirinya sebagai pribadi yang unik & 1 & $5.9 \%$ \\
\hline 9 & $\begin{array}{l}\text { Menunjukkan dirinya sebagai pribadi yang mengikuti } \\
\text { isu dan tren terkini }\end{array}$ & 3 & $17.6 \%$ \\
\hline 10 & Menunjukkan dirinya sebagai pribadi yang mandiri & 0 & $0.0 \%$ \\
\hline 11 & $\begin{array}{l}\text { Menunjukkan dirinya sebagai pribadi yang } \\
\text { kontemporer/modern }\end{array}$ & 2 & $11.8 \%$ \\
\hline
\end{tabular}

Berdasarkan tabel di atas, dimensi excitement didominasi oleh indikator yang menunjukkan dirinya sebagai pribadi yang bersemangat. Indikator terbanyak kedua terdiri dari indikator yang menunjukkan dirinya sebagai pribadi yang mengasyikkan dan pribadi yang imajinatif. Tidak ditemukan konten yang menunjukkan indikator berani dan mandiri.

Indikator lain yang muncul adalah menunjukkan pribadi yang trendi, keren, muda, dan unik dengan persentase yang sama. Selain itu, Achmad Zaky juga menunjukkan dirinya sebagai orang yang mengikuti isu dan tren terkini serta sebagai pribadi yang kontemporer.

Tabel 10. Competence

\begin{tabular}{|c|c|c|c|}
\hline No & Indikator & Jumlah & Persentase \\
\hline 1 & $\begin{array}{l}\text { Menunjukkan dirinya sebagai pribadi yang bisa } \\
\text { diandalkan }\end{array}$ & 1 & $5.9 \%$ \\
\hline 2 & $\begin{array}{l}\text { Menunjukkan dirinya sebagai pribadi yang bekerja } \\
\text { keras }\end{array}$ & 6 & $35.3 \%$ \\
\hline 3 & Menunjukkan dirinya sebagai pribadi yang mapan & 3 & $17.6 \%$ \\
\hline 4 & Menunjukkan dirinya sebagai pribadi yang cerdas & 5 & $29.4 \%$ \\
\hline 5 & Menunjukkan kapasitas dalam hal teknis & 1 & $5.9 \%$ \\
\hline 6 & Menunjukkan peran di perusahaan & 5 & $29.4 \%$ \\
\hline 7 & Menunjukkan dirinya sebagai orang yang sukses & 6 & $35.3 \%$ \\
\hline 8 & Menunjukkan dirinya sebagai pemimpin & 4 & $23.5 \%$ \\
\hline 9 & $\begin{array}{l}\text { Menunjukkan dirinya sebagai pribadi yang memiliki } \\
\text { kepercayaan diri }\end{array}$ & 4 & $23.5 \%$ \\
\hline
\end{tabular}


Dalam dimensi competence, indikator yang paling sering muncul merupakan indikator yang menunjukkan dirinya pribadi yang bekerja keras dan sukses. Indikator kedua terbanyak merupakan indikator yang menunjukkan dirinya sebagai pribadi yang cerdas. Indikator dengan frekuensi kemunculan terendah merupakan indikator yang menunjukkan pribadi yang bisa diandalkan dan hal teknis. Indikator yang menunjukkan dirinya sebagai pemimpin dan pribadi yang memiliki kepercayaan diri memiliki frekuensi kemunculan yang sama.

Tabel 11. Sophistication

\begin{tabular}{l|lll}
\hline No & Indikator & Jumlah & Persentase \\
\hline 1 & Menunjukkan gaya hidup kelas atas & 4 & $23.5 \%$ \\
2 & Menunjukkan dirinya sebagai individu yang rupawan & 1 & $5.9 \%$ \\
3 & Menunjukkan dirinya sebagai individu yang menarik & 0 & $0.0 \%$ \\
4 & Menunjukkan dirinya sebagai individu yang menawan & 0 & $0.0 \%$ \\
5 & Menunjukkan dirinya sebagai individu yang feminim & 0 & $0.0 \%$ \\
6 & Menunjukkan dirinya bertutur kata halus & 3 & $17.6 \%$ \\
\hline
\end{tabular}

Temuan dalam dimensi sophisticaiton berdasarkan tabel di atas menunjukkan bahwa indikator yang mendominasi merupakan indikator yang menunjukkan gaya hidup kelas atas, disusul indikator yang menunjukkan dirinya bertutur kata halus. Tidak ditemukan adanya indikator yang menunjukkan dirinya sebagai individu yang menarik, menawan, dan feminim. Indikator ketiga yang paling sering muncul adalah menunjukkan dirinya sebagai pribadi yang rupawan.

Tabel 12. Ruggedness

\begin{tabular}{r|lll}
\hline No & Indikator & Jumlah & Persentase \\
\hline 1 & $\begin{array}{l}\text { Menunjukkan dirinya sebagai individu yang menyukai } \\
\text { kegiatan di luar ruangan }\end{array}$ & 3 & $17.6 \%$ \\
2 & Menunjukkan dirinya sebagai individu yang maskulin & 0 & $0.0 \%$ \\
3 & $\begin{array}{l}\text { Menunjukkan dirinya sebagai individu yang } \\
\text { mengadopsi pengaruh Barat }\end{array}$ & 0 & $0.0 \%$ \\
4 & Menunjukkan dirinya sebagai individu yang kuat & 2 & $11.8 \%$ \\
5 & Menunjukkan dirinya sebagai individu yang kasar & 0 & $0.0 \%$ \\
\hline
\end{tabular}

Dimensi terakhir merupakan dimensi ruggedness. Dari temuan yang didapat, indikator terbanyak merupakan indikator yang menunjukkan kegiatan di luar ruangan. Indikator terbanyak kedua adalah indikator yang menunjukkan dirinya sebagai individu yang kuat. Tidak ditemukan adanya konten yang memiliki indikator maskulin, pengaruh Barat, dan kasar dalam sampel konten yang diambil dalam periode ini. 


\section{Perbandingan Brand Personality Achmad Zaky dalam Dua Set Data}

Penelitian ini berusaha mendapatkan pemahaman mengenai dimensi brand personality yang digunakan oleh Achmad Zaky dalam akun Instagram @achmadzaky melalui konten berupa foto dan video. Terdapat dua set data yang dianalisis untuk mendapatkan hasil yang dapat dibandingkan satu sama lain. Hal ini dilakukan mengingat pada tanggal 14 Februari 2019, terdapat repon negatif khalayak melalui tagar \#UninstallBukalapak di berbagai media sosial terkait pernyataan Achmad Zaky di Twitter yang dinilai politis.

Untuk dapat memahami lebih lanjut, peneliti memaparkan hasil yang membandingkan dimensi brand personality yang muncul dalam dua set data sebagai berikut.

Tabel 13. Brand Personality dalam dua set data

\begin{tabular}{r|llll}
\hline \multicolumn{1}{c}{ Variabel } & \multicolumn{3}{c}{ Data Set 1 } & Data Set 2 \\
\cline { 2 - 5 } & Jumlah & Persentase & Jumlah & Persentase \\
Sincerity & 28 & $68.3 \%$ & 13 & $76.5 \%$ \\
Excitement & 31 & $75.6 \%$ & 9 & $52.9 \%$ \\
Competence & 34 & $82.9 \%$ & 13 & $76.5 \%$ \\
Sophistication & 6 & $14.6 \%$ & 6 & $35.3 \%$ \\
Ruggedness & 12 & $29.3 \%$ & 4 & $23.5 \%$ \\
\hline
\end{tabular}

Berdasarkan tabel di atas, tidak terdapat perbedaan yang signifikan. Pada set data pertama, dimensi brand personality yang memiliki frekuensi kemunculan tertinggi adalah dimensi excitement dan competence. Pada set kedua dimensi yang paling sering muncul adalah dimensi sincerity dan competence. Pada dasarnya, konten Achmad Zaky didominasi oleh dimensi sincerity, excitement, dan competence, meskipun terdapat perbedaan dalam frekuensi kemunculan dimensi tersebut pada dua set data.

Pada data set pertama, dimensi competence memiliki frekuensi sebesar 82.9\%, sedangkan pada data set kedua, dimensi ini memiliki persentase sebesar 76.5\%. Dimensi sincerity pada data set pertama memiliki persentase sebesar 68.3\%, sedangkan pada data set kedua memiliki persentase sebesar 76.5\%. Dimensi excitement pada set data pertama memiliki persentase kemunculan sebesar $75.6 \%$, sedangkan pada set data kedua dimensi ini memiliki persentase sebesar 52.9\%. Terdapat penurunan sebesar $6.4 \%$ dalam dimensi competence pada set data kedua, peningkatan sebesar $8.2 \%$ dalam dimensi sincerity pada set data kedua, dan penurunan sebesar $22.7 \%$ dalam dimensi excitement pada set data kedua.

Terjadi peningkatan dalam dimensi sophistication pada set data kedua, yaitu sebesar $20.7 \%$. Pada set data pertama, dimensi ini memiliki persentase sebesar $14.6 \%$, sedangkan pada set data kedua memiliki persentase $35.3 \%$. Dimensi ruggedness pada set data pertama memiliki persentase sebesar $29.3 \%$, dan $23.5 \%$ pada set data kedua. Hal ini menunjukkan adanya penurunan sebesar 5.8\% dalam dimensi ini pada set data kedua. 
Perlu diperhatikan sebagai perbedaan paling mendasar dalam penelitian ini adalah sample dalam masing-masing set data itu sendiri. Dari total keseluruhan 58 jumlah sample, set data pertama memiliki jumlah sebesar 41 , dan set data kedua memiliki jumlah sample sebesar 17. Terdapat perbedaan sebesar $41.5 \%$ dalam jumlah konten pada periode set data pertama dan set data kedua.

Hal ini menunjukkan bahwa pada periode 5 Desember 2018 hingga 13 Februari 2019, frekuensi Achmad Zaky dalam mengunggah konten di akun Instagram lebih banyak dibandingkan periode 14 Februari hingga 5 Mei 2019. Terdapat perbedaan yang signifikan dalam jumlah konten dari sebelum dan sesudah pernyataan Achmad Zaky di Twitter yang dinilai politis dan menimbulkan respon khalayak yang berupa tagar \#UninstallBukalapak di berbagai media sosial.

Dapat diartikan bahwa respon khalayak melalui \#UninstallBukalapak mempengaruhi perilaku Achmad Zaky dalam media sosial, termasuk dalam brand personality yang ingin disampaikan. Hal ini mengacu pada dalam tidak hanya perusahaan yang dapat mempengaruhi nilai melalui komunikasi langsung, namun juga individu-individu yang ada di dalamnya (McCracken, 1989 dalam Maehle \& Supphellen, 2011). Perilaku Achmad Zaky di media sosial dapat mempengaruhi nilai dari perusahaan yang dipimpinnya, yaitu Bukalapak.

Secara keseluruhan, penelitian ini berusaha untuk menempatkan konsep brand personality yang dikembangkan oleh Aaker (1997) dalam konteks media sosial dan individu yang merepresentasikan suatu perusahaan. Penelitian ini juga berusaha menggambarkan bagaimana individu yang merepresentasikan perusahaan dapat mempengaruhi identitas perusahaan tersebut serta perubahan perilaku yang didasari oleh respon khalayak terhadap individu dan perusahaan. Dalam hal ini, Achmad Zaky sebagai pendiri dan CEO Bukalapak dapat mempengaruhi persepsi khalayak terhadap perusahaan, dan mengubah perilaku media sosial berdasarkan respon khalayak, secara khusus dalam dimensi brand personality.

Sebagai salah satu aspek dalam membentuk identitas, brand personality merupakan aspek penting yang harus disampaikan kepada khalayak. Penggunaan media sosial seperti Instagram dapat menjadi medium yang ideal untuk menunjukkan brand personality dikarenakan bentuk konten yang ditampilkan tidak hanya dalam bentuk teks, namun juga berupa foto dan video.

\section{Simpulan}

Dengan popularitas Instagram, organisasi seperti perusahaan berusaha untuk menemukan suatu cara untuk menciptakan nilai brand melalui konten untuk lebih menonjol dibandingkan kompetitor mereka (Putri Kinanti \& Primadani Satria Putri, 2017). Perusahaan dapat menghubungkan brand dengan konsumen secara langsung melalui media sosial melalui konten-konten yang menarik minat penggunanya (Rustono Farady Marta \& Monica William, 2016). Salah satu aspek untuk menciptakan identitas perusahaan adalah brand personality yang diartikan sebagai elemen yang dapat merefleksikan nilai perusahaan, kata dan tindakan dari pekerja dalam suatu perusahaan (Ritchey \& Keller, 2006 dalam Chang, 2014). 
Dari hasil temuan dan diskusi dari penelitian ini mengenai brand personality yang ditampilkan oleh Achmad Zaky sebagai pendiri dan CEO Bukalapak melalui akun Instagram @achmadzak, didapati bahwa terdapat perbedaan dari dimensi brand personality yang ditampilkan dan jumlah konten yang menjadi sampel dari dua set data yang didasari oleh periode respon khalayak yang berbentuk tagar \#UninstallBukalapak.

Kesimpulan yang dapat ditarik dari penelitian ini adalah terdapat perbedaan dari dimensi brand personality yang ditampilkan oleh akun Instagram @achmadzaky dan jumlah konten yang menjadi sampel dari dua set data yang didasari oleh periode respon khalayak yang berbentuk tagar \#Bukalapak di berbagai media sosial.

Secara keseluruhan, konten Achmad Zaky di Instagram didominasi oleh dimensi sincerity, excitement, dan competence, sedangkan dimensi sophistication dan ruggedness merupakan dimensi dengan frekuensi kemunculan terendah dalam dua data set yang berbeda. Terdapat perbedaan dalam frekuensi kemunculan dalam masing-masing dimensi brand personality pada dua set data.

Perbedaan lain yang paling mendasar adalah jumlah sampel dari masingmasing set data. Dengan durasi waktu yang sama, set data pertama memiliki jumlah sampel sebesar 41 konten, sedangkan 17 konten pada set data kedua. Hal ini menunjukkan terdapat penurunan $41.5 \%$ dalam frekuensi unggahan konten di akun Instagram @achmadzaky setelah pernyataannya di Twitter yang menimbulkan respon khalayak yang berupa tagar \#UninstallBukalapak di berbagai media sosial.

Perlu dilakukan penelitian lebih lanjut mengenai persepsi khalayak mengenai brand personality terhadap Achmad Zaky. Hal ini untuk mendapatkan gambaran menyeluruh untuk mengetahui dimensi brand personality dominan yang ditampilkan oleh Achmad Zaky dan dimensi brand personality dominan yang terdapat dalam persepsi khalayak. Selain itu, kajian lebih lanjut juga dapat dilakukan terhadap identifikasi brand personality yang terdapat dalam akun Instagram @achmadzaky dan akun Instagram @bukalapak. Hal ini dapat dilakukan untuk melihat keselarasan dari brand personality yang ditampilkan oleh pemimpin perusahaan dan perusahaan itu sendiri.

\section{Ucapan Terima Kasih}

Penulis mengucapkan terima kasih yang sebesar-besarnya kepada semua pihak yang membantu terlaksananya penelitian ini hingga dapat dipublikasikan, khususnya dosen dan rekan mahasiswa di Program Pascasarjana Ilmu Komunikasi Universitas Indonesia, serta editor di Jurnal Komunikasi Universitas Tarumanagara yang telah memberikan masukan konstruktif bagi penelitian ini. 
Ricardo Taufano, Irwansyah: Brand Personality Achmad Zaky Sebagai Chief Executive Officer Bukalapak Dalam Media Sosial Instagram

\section{Daftar Pustaka}

Aaker, J. (1997). Dimensions of Brand Personality. In Journal of Marketing Research, Vol. 34, No. 3. https://doi.org/10.2139/ssrn.945432

Bendisch, F., Larsen, G., \& Trueman, M. (2013). Fame and fortune: A conceptual model of CEO brands. European Journal of Marketing. https://doi.org/10.1108/03090561311297472

Chang, C. Y. (2014). Visualizing brand personality and personal branding: case analysis on Starbucks and Nike' s brand value co-creation on Instagram. Thesis. https://doi.org/10.17077/etd.8y3v071r

Chematony, L. de. (1999). Brand Management Through Narrowing the Gap Between Brand Identity and Brand Reputation. Journal of Marketing Management, 15.

Ghodeswar, B. M. (2008). Building brand identity in competitive markets: A conceptual model. Journal of Product \& Brand Management. https://doi.org/10.1108/10610420810856468

Lieven, T. (2018). Brand Gender: Increasing Brand Equity through Brand Personality. In Brand Gender: Increasing Brand Equity through Brand Personality. https://doi.org/10.1007/978-3-319-60219-6

Maehle, N., \& Supphellen, M. (2011). In Search of the Sources of Brand Personality. International Journal of Market Research. https://doi.org/10.2501/ijmr-53-1-095-114

Marta, Rustono Faradi, Fernando, J., \& Simanjuntak, R. F. (2019). Eksplikasi Kualitas Konten Peran Keluarga Pada Instagram @Kemenppa. Ettisal: Journal of Communication, 4(2).

Marta, Rustono Farady. (2018). Polemik Kebhinnekaan Indonesia Pada Informasi Instagram @Infia_Fact Terkait Patung Kwan Sing Tee Koen Tuban. Bricolage: Jurnal Magister Ilmu Komunikasi, 3(02), 63-71. https://doi.org/10.30813/bricolage.v3i02.922

Marta, Rustono Farady, Fernando, J., \& Kurniawati, L. S. M. W. (2020). Tinjauan Peran Komunikasi Keluarga pada Kinerja Public Relations melalui Konten Laman Resmi Media Daring KPPPA. Jurnal Komunikasi Pembangunan, 18(01), 30-42. https://doi.org/10.22500/18202028620

Marta, Rustono Farady, \& Monica William, D. M. W. (2016). Studi Terpaan Media Pemasaran Melalui Posting Instagram Terhadap Ekuitas Merek Pelanggan Sumoboo! Jurnal Komunikasi Untar, 8(1), 68-82.

Nandan, S. (2007). An exploration of the brand identity-brand image linkage: A communications perspective. Journal of Brand Management. https://doi.org/10.1057/palgrave.bm.2540222

Neuman, W. L. (2014). Social Research Methods: Qualitative and Quantitative Approaches. In Pearson Education Limited. https://doi.org/10.2307/3211488

Potter, W. J., \& Levine-Donnerstein, D. (1999). Rethinking validity and reliability in content analysis. Journal of Applied Communication Research. https://doi.org/10.1080/00909889909365539 
Putri Kinanti, S., \& Primadani Satria Putri, B. (2017). Pengaruh Media Sosial Instagram @Zapcoid Terhadap Brand Equity Zap Clinic. Jurnal Komunikasi, 9(1), 53-64. Retrieved from https://media.neliti.com/media/publications/137697-ID-pengaruh-mediasosial-instagram-zapcoid.pdf

Roberts, C. W. (2015). Content Analysis. In International Encyclopedia of the Social \& Behavioral Sciences: Second Edition. https://doi.org/10.1016/B978-0-08-097086-8.44010-9

Sapoetri, A., \& Pannindriya, S. T. (2019). Geliat Interaksi Sosial Dokter Masa Kini Melalui Media Sosial Instagram. Bricolage: Jurnal Magister Ilmu Komunikasi, 5(02), 121. https://doi.org/10.30813/bricolage.v5i2.1884

Stevani, S., \& Widayatmoko, W. (2017). Kepribadian Dan Komunikasi Susi Pudjiastuti Dalam Membentuk Personal Branding. Jurnal Komunikasi, 9(1), 65. https://doi.org/10.24912/jk.v9i1.225

Teguh, M., \& Ciawati, S. T. (2020). Perancangan Strategi Digital Marketing Communication Bagi Industri Perhotelan dalam Menjawab Tantangan Era Posmodern. Bricolage : Jurnal Magister Ilmu Komunikasi, 6(1), 51-64.

White, M. D., \& Marsh, E. E. (2006). Content Analysis: A Flexible Methodology. Library Trends. https://doi.org/10.1353/lib.2006.0053 